\title{
Larry Alexander and Kimberly Kessler Ferzan on Omissions and Normative Ignorance: A Critical Reply
}

\author{
Douglas Husak $^{1}$ (i)
}

Accepted: 17 December 2020 / Published online: 8 January 2021

(c) The Author(s) 2021

\begin{abstract}
Reflections on Crime and Culpability seeks to elaborate, extend, and occasionally qualify the insights reached by Larry Alexander and Kim Ferzan in their influential prior collaboration, Crime and Culpability. They deftly explore any number of new issue that all criminal theorists should be encouraged to address. In my essay, I discuss and challenge their positions on omissions as well as on moral ignorance. Their treatment of the latter issue is a clear improvement over that in their earlier book. But their views on omissions suggest to me that they should have had reservations about some of the most fundamental claims of their overarching theory.
\end{abstract}

Keywords Alexander and Ferzan · Omissions · Moral ignorance · Culpability · Wrongdoing · Causation

\section{Introduction}

Typically, authors write a book in which they identify a thesis and try their best to defend it. Larry Alexander and Kim Ferzan did so in their much-celebrated Crime and Culpability: A Theory of Criminal Law. ${ }^{1}$ Rarely do authors write a second book in which they attempt to correct what they concede they got wrong or explore what they overlooked in their earlier work. Reflections on Crime and Culpability is among these rare exceptions. Although a few of the central theses of its predecessor are qualified and even questioned, none is abandoned altogether. Thus, potential readers in the universe of criminal law theorists might be excused for not bothering to read

\footnotetext{
${ }^{1}$ Larry Alexander and Kimberly Kessler Ferzan with Stephen Morse: Crime and Culpability: A Theory of Criminal Law (Cambridge: Cambridge University Press, 2009).

Douglas Husak

husak@philosophy.rutgers.edu

1 Rutgers University, New Brunswick, USA
} 
it. After all, most have already come to terms with what they accept or reject about the very controversial views of Alexander and Ferzan (I resist the nearly overwhelming temptation to call them "Ferzander," largely because of awkwardness and uncertainty about whether the author(s) is/are singular or plural, masculine or feminine).

This dismissive reaction is almost certainly mistaken. Although the authors announce that "the purpose of this book is to remedy those shortcomings" of Crime and Culpability, they immediately add that "many of those problems and puzzles are not just problems and puzzles for us. Some are problems and puzzles for other retributivists, and some are problems and puzzles for all punishment theorists" (1). To a great extent, they are correct. Reflections on Crime and Culpability addresses any number of thorny questions in the philosophy of criminal law that all theorists too often neglect. Proxy crimes, volume discounts, and problems in the distribution of retributive desert present difficulties for many theorists in addition to Alexander and Ferzan. Despite my best efforts to do so, however, the fact that the authors conceptualize many of the issues they discuss from the peculiar perspective of their own theory is oftentimes impossible to overlook. To be sure, Alexander and Ferzan have already heard many of these objections before, and, for better or worse, have found them to be unpersuasive. ${ }^{2}$ Still, I fear that several of these old problems resurface when they examine many of the novel issues they did not confront the first time around.

Before focusing on two of the relatively new topics they address-whether and under what conditions criminal liability should attach to an omission, and whether and under what conditions criminal liability should be imposed for conduct the defendant mistakenly believes to be permissible-I will follow Alexander and Ferzan and reproduce from their opening chapter a bit of their summary of their overall position. Fortunately, no one needs to re-read their first book to understand the outlines of the unusual approach they take. "Criminal liability," they write, "should be based solely on the defendant's culpability, and the degree of culpability should be the measure of the punishment the defendant deserves" (1). In addition, "the culpability that grounds retributive desert is constituted by two things. The first is the risks of various harms to the morally (and we will assume legally) protectable interests of others the defendant believes his act endangers - that is, the risk of harms that he believes his act unleashes and places out of his control to affect. The second is the defendant's belief as to the existence of any facts at the time of his act that might justify or excuse the act, mitigate its culpability, or aggravate its culpabilityall discounted by the defendant's estimate of the probability that those facts do or do not exist." In case there is doubt, they add that their account of culpability is thoroughly subjective: "Our argument was and is that in determining the defendant's culpability, it is his perspective and estimates that matter... no matter what is in fact the case" (2).

\footnotetext{
${ }^{2}$ Many of the exchanges are contained in Heidi M. Hurd, ed.: Moral Puzzles and Legal Perplexities: Essays on the Influence of Larry Alexander (Cambridge: Cambridge University Press, 2019).
} 
Although I am critical of a great deal about Alexander and Ferzan's theory, their candidate for a principle of culpability is not my main target. It is hardly radical to contend that culpability consists in a subjective disregard for the legitimate interests of others. My reservation is not that they have done a bad job identifying a culpable state, but that they oversimplify by supposing they have identified the only culpable state. Although I will not press this worry, I strongly doubt that all kinds of culpability can be squeezed into this formula without distortion. Can the underlying structure of criminal law possibly be so simple? I mention this point because I want to report my agreement that they have done a decent job articulating a central (if not the sole) mode of culpability.

Still, it is tempting to critique their theory at its foundations. It certainly has some radical and noteworthy implications Alexander and Ferzan rehearse in their introduction. For example, they reject negligence as a mode of culpability, have no patience for taking causal or circumstantial luck into account, believe liability for incomplete attempts is indefensible, and, perhaps most surprisingly of all, reduce all of the many crimes in criminal codes to a single kind. Although they have been instrumental in persuading me that blame for negligence is hugely problematic, I find each of these additional supposed implications to be increasingly implausible. I want to dwell in particular on the latter claim - that only a single crime exists-inasmuch as I do not understand it or its alleged connection to their overall theory. I have oftentimes been unsure whether Alexander and Ferzan take themselves to be producing a theory of wrongdoing in addition to a theory of culpability. In their hands, these two dimensions tend to blur into one amorphous whole. Wrongdoing looms large in some contexts; in others, it seems to vanish entirely as an independent condition of liability. To be sure, it is hard to believe that such distinguished criminal theorists overlook this familiar distinction, so I may be guilty of misunderstanding them. Alexander and Ferzan certainly believe that there exists only one kind of culpability - summarized in the preceding paragraph. But why does a single type of culpability entail a single type of crime?

I quote what they specifically say about this matter. They confess that "one of the most controversial aspects of our proposal is that we do away with specific crimes, such as murder, battery, theft, arson and rape. Legally protected interests are multiple, but crimes that threaten those interests are just different manifestations of a single crime" (7). And what exactly is this single crime? They answer that the "single crime [is] any act that demonstrates the actor's insufficient concern for these interests. For us, the culpability of an act is a product of all the harms the defendant believes he is risking" (7). On another occasion, they write "there is only one criminal law, which could be characterized as 'act with sufficient concern for others' legally protected interests", (61). I have a hard time understanding this answer. The account they offer of the alleged single crime looks an awful lot like the account they offer of the alleged single culpable state. They seemingly respond to my question by claiming that the "single crime" they countenance is the culpability that actors manifest whenever they commit it. In other words, any time an agent acts culpably, he commits the single crime their theory countenances. But even though the problem of crime individuation is notoriously difficult, one would think there are (at least) as many crimes as there are legally protected interests. It is not too outlandish 
to reduce all culpable states to a single kind, but it is outlandish to reduce all legally protected interests to a single kind of offense. Admittedly, I am unsure that my interpretation quite captures what Alexander and Ferzan really mean, as sometimes they seemingly allow that a person can act culpably without incurring liability because she has not violated a protected interest. But what $i s$ wrongdoing if not the violation of a protected interest? If an agent manifests culpability even though he does not violate a protected interest, isn't it true that he does not incur liability because his conduct is not wrongful? Thus, if a defendant is to be criminally liable, wrongdoing is required in addition to culpability after all. Or so it appears to me.

Let me try to explain my concern further. Suppose I made the radical suggestion that intention is the only culpable state a theory of criminal law should recognize. Contrary to existing law, liability and punishment should not be imposed on persons who merely act knowingly, recklessly, or negligently. I am sure no one would construe this peculiar suggestion to entail that only one crime exists, namely, the crime of acting intentionally or the crime of violating legally protected interests intentionally. I would be understood to retain homicide, counterfeiting, burglary, rape, and other crimes in my code - as long as it was clear that a defendant could not be liable or subject to punishment for committing one of these crimes unless she did so intentionally. I would not be interpreted to suggest that homicide, counterfeiting, burglary, and rape were all "manifestations" of a single crime of intent. Why should Alexander and Ferzan think otherwise? Why should they think that the existence of a single culpable state - a proposition for which they argue extensively-somehow entails or is tantamount to the existence of a single crime- a proposition for which, as far as I can see, they argue not at all.

To minimize the potential for misunderstanding, let me repeat what Alexander and Ferzan say about this matter elsewhere, in an article largely devoted to a defense of their position that a single criminal law exists: "To us, then, there is really only one injunction that is relevant to criminal culpability: chose only those acts for which the risks to others' interests - as you estimate those risks - are sufficiently low to be outweighed by the interests, yours and others' that you are attempting to advance (discounted by the probability, as you perceive it, of advancing those interests)." 3 They then conclude: "In Model Penal Code parlance, we have done away with the special part of the criminal code." 4

I worry that Alexander and Ferzan do not (because they reasonably cannot) preserve the implications of this position throughout Reflections on Crime and Culpability. To understand why it is so hard to do away with an independent requirement of wrongdoing, I propose to dwell on two new issues they discuss. I first examine their position about liability for omissions before turning to their treatment of how ignorance bears on culpability.

\footnotetext{
${ }^{3}$ Larry Alexander and Kimberly Kessler Ferzan: "Beyond the Special Part," in R.A. Duff and Stuart Green, eds.: Philosophical Foundations of Criminal Law (Oxford: Oxford University Press, 2011), p.253, 255.

4 Id., p. 255.
} 


\section{Omissions}

The topic of omissions has generated a massive literature that is nuanced and complex. Yet Alexander and Ferzan succeed in offering some fascinating and original perspectives on this well-worn topic. For example, they point out that the temporal duration of quite a few criminal omissions is significantly longer than an instant, the time required to complete most criminal acts. For example, a wrongdoer may have ample opportunities over several hours to put out a fire he has recklessly started. Thus, his culpability may vary from one moment to the next-from indifference to malice and back again. Orthodox thought, I gather, tends to fix the blameworthiness of the omitter at the highest level he exhibits during this extended duration. Alexander and Ferzan reject this orthodox position. Instead, they posit that culpability in these situations is better construed as additive. As far as I can determine, their preference for an additive view is driven by intuitions about kinds of cases, most of which begin with a culpable action. If an assassin fires a fatal shot but his victim dies over a period of several days, for example, the wrongdoer is also likely to be guilty of a failure to rescue the person he has mortally wounded. Thus, I surmise they believe that (ceteris paribus) an instantaneous killing typically confers less culpability on an agent than a killing that takes place over time, inasmuch as a defendant who kills over time is likely to also be guilty of a greater amount of culpable conduct. Readers will disagree about whether this result is correct. Although I have my doubts on the level of intuition, it is difficult to say exactly why Alexander and Ferzan are mistaken. Does the subsequent omission somehow merge with the prior wrongful act-much as attempts merge with completed crimes? Does merger depend on how many opportunities are available to the omitter to rescue the victim he has harmed? I am unsure. Alexander and Ferzan should at least be credited with taking this problem seriously. This problem is among those that must be faced by all philosophers of criminal law, regardless of the overarching theory they hold.

But I am less concerned to dwell on their novel perspective about the duration of omissions than to connect their general thoughts about omissions to their larger theory. The discrepancies between what they say about omissions and what they say elsewhere are startling. In the hands of Alexander and Ferzan, I would have thought the problem of omissions should be simple_-as simple as the rest of criminal law. Under what circumstances do we merit blame for our failure to act to help someone we believe would otherwise be injured, that is, injured but for our failure to act? Their answer should be easy to state (although applying it might be difficult): One need only determine whether the failure to act in a given circumstance is culpable-which amounts to a determination of the risks of various harms to the morally protected interests of others the defendant believes his conduct endangers (plus his beliefs about the existence of any facts at the time of his conduct that might justify or excuse it). In the foregoing sentence, notice 
I substitute "conduct" for "act" in Alexander and Ferzan's description of their overarching principle. In other words, I see no reason to differentiate between acts and omissions in describing and applying their general theory of culpability, that is, to differentiate between cases in which a defendant displays indifference to the interests of others through her acts as opposed to through her omissions. As with acts, whether a defendant really violates a legally protected interest would seem to be immaterial. What should matter to culpability and blameworthiness is whether she believes she is doing so, not whether her belief is true.

Not too surprisingly, however, Alexander and Ferzan do not embrace this straightforward application of their theory. This implication would have the result of expanding the scope of liability and punishment for omissions far beyond where they propose to confine it. ${ }^{5}$ A handful of moral philosophers might be prepared to take this plunge, but Alexander and Ferzan are not among them in leaping into the abyss. Instead, in this domain, they invoke the (otherwise neglected) contrast between (what I take to be) wrongdoing and culpability to support a very conventional account of the circumstances under which penal liability for an omission should be imposed. As most textbooks indicate, liability for an omission is imposed only when one of four "triggers" exists: (1) when the defendant and victim stand in a given status relationship; (2) when the defendant voluntarily obligates himself to rescue the victim from peril; (3) when a statute creates a duty to assist; or (4) when the defendant creates the peril of the victim. Alexander and Ferzan contend that this textbook account is correct. Thus, in the context of omissions, at least, they hold that whether a given defendant thinks he is infringing a morally protected interest turns out to be neither here nor there. What ultimately matters is whether he is.

What Alexander and Ferzan call "triggers," most theorists would describe as "duties." Their shift in labels may distract attention from the fact that duties pertain to wrongdoing, not to culpability. Thus, to require a trigger or a duty as a precondition of liability for omissions is to require wrongdoing - a requirement they resist elsewhere. Let me be more specific. Suppose a defendant believes she is disregarding a legal and moral duty by demonstrating what she regards as callous indifference to the pleas of a desperate panhandler. She believes this panhandler will die as a result of her failure, which she mistakenly thinks qualifies and is punishable as a token of murder. Of course, victims have a legally protected interest in not being murdered, an interest the defendant believes she is violating. Nonetheless, Alexander and Ferzan deny that liability should be imposed in this situation because none of the four objective triggers to liability obtain. I ask: do they think that liability is unjustifiable in my example because the failure to help the desperate panhandler is not wrongful? Alexander and Ferzan cannot give this answer, because their theory dispenses with an independent element of wrongdoing. Is liability thus unjustifiable because the failure to help the desperate panhandler is not culpable? I do not see how this answer can be given either, because culpability depends exclusively on what the defendant believes, and I have stipulated that the defendant believes her

\footnotetext{
5 Depending on what a given defendant believes, it also could have the result of contracting the scope of liability, but I will not pursue this point here.
} 
deliberate failure to help manifests a callous disregard of the risks to the interests of another that amounts to murder.

I construe Alexander and Ferzan to deny that liability is justifiable because no "trigger" to liability exists, that is, because the defendant has no duty to help the panhandler. In this domain, the objective triggers function to describe an exhaustive list of our legal duties, that is, of the circumstances under which it is wrongful to omit. In other words, in the context of omissions, culpability alone (as it exists in the head of the defendant) is inadequate to support penal liability and deserved punishment. The conventional account they adopt here is starkly at odds with what is otherwise a theory with enormously radical implications for reforming the law as it is. Thus, their narrow and orthodox account of triggers or legal duties prevents their theory of culpability from fundamentally transforming the scope of liability for omissions.

So far, I have contended that Alexander and Ferzan renege on their basic commitment to make liability turn exclusively on culpability with no room for a separate element of wrongdoing. In my judgment, however, the problem with their treatment of omissions extends deeper, to some of the details as well as to the foundations. I have long been puzzled by the fourth of their above triggers, viz., "creation of a peril." Although Alexander and Ferzan admit that this "category of legal duty" presents "a knotty theoretical problem" (66), I fear they minimize its perplexities. I believe they mischaracterize this trigger and extend it beyond its legitimate boundaries. When does a defendant create a victim's peril such that his subsequent omission violates a duty? They answer that all such cases have the following structure: "A defendant at $\mathrm{t} 1$ engages in an act that is not culpable, but, in the absence of a subsequent act by the defendant or someone else, will likely eventuate in harm to a victim" (69). If I understand this abstract description correctly, I submit it is too broad to accurately capture the cases in which a defendant could be said to have created a peril and thus to have a duty to help those victims whose peril he has created.

Consider a simple example to illustrate the uncertainties. Suppose I enter a restaurant at $\mathrm{t} 1$ (not a culpable act) and soon notice at $\mathrm{t} 2$ a patron sitting several tables away who is choking on a chicken bone. In the absence of a subsequent act by me or by someone else, I realize that the victim is likely to suffer serious injury. Although I believe that this example matches the abstract structure they offer above, I am certain we agree that I have not "created" the victim's peril. Why not? Does their answer emphasize what I did at $\mathrm{t} 1$ ? In other words, do they deny that my initial act of entering the restaurant at $\mathrm{t} 1$ is "likely [to] eventuate in harm to a victim?" This answer seems literally correct but unhelpful to Alexander and Ferzan for a number of distinct reasons. First, surely I can act at t1 to create a peril I must subsequently ameliorate even though it was not likely to eventuate in harm-from routine, everyday activities, for example. Moreover, would it be relevant to my ultimate liability if the particular restaurant had a hard-earned reputation for harming its patrons? In addition, must I be aware that harm is likely to eventuate? After all, since culpability is thoroughly subjective, why are the actual probabilities of harm material to my liability rather than my personal estimate of them? Finally, if this trigger requires that harm must be "likely to eventuate" from my act at t1, why make the curious stipulation that my act is nonculpable? Thus, I construe their requirement that harm 
will "eventuate" to the victim to follow from my subsequent act, that is, my failure to assist at $\mathrm{t} 2$. For the foregoing reasons, however, I am unsure.

To resolve my uncertainties, I need to know more about what they mean by "eventuate." Presumably, it is a causal relation. Thus, my act at t1 would not be said to "eventuate" in whatever subsequent harms just happen to take place without a causal contribution on my part. But if "eventuates" is causal, Alexander and Ferzan can be construed to announce the uninformative platitude that I create whatever perils I cause, and have a subsequent duty to do what is needed to prevent those perils from resulting in harm. In any event, "creates," is unquestionably causal, and only counterfactual dependence, not causation, is (at best) present in my example in which harm "eventuates." If other patrons in the restaurant have an opportunity to assist, as their foregoing structure allows, I have described a case of overdetermination in which not even counterfactual dependence obtains. In short, I did not create the peril of the choking victim because I did not cause it and it is not even counterfactually dependent on my failure to help. Most importantly, however, as readers of Crime and Culpability will be aware, Alexander and Ferzan are famously unwilling to suppose that causation plays much of a role in their theory of criminal liability. Hence I understand their reluctance to invoke causation (and thus to substitute "eventuation") in their abstract description of when a defendant creates a peril. But "eventuates" is unanalyzed.

Without invoking a conception of causation, Alexander and Ferzan are bound to have difficulty specifying what liability is for. Any good theory of omissions should identify whether liability is for the failure to act or for the harm produced by the failure to help. The contrast between these alternatives is easy to draw. Suppose defendants \#1 and \#2 at $\mathrm{t} 1$ both engage in an act that is not culpable, but, in the absence of a subsequent act by these defendants or someone else, will likely eventuate in harm to a victim. D1's victim chokes to death from the peril created (or eventuated) by D1, but D2's victim succeeds in dislodging the bone and escapes unscathed. Both D1 and D2 performed the same act at t1; what differentiates their situations is causal (or eventuational) luck. If such luck is irrelevant to liability, as Alexander and Ferzan hold, how can D1 but not D2 be liable for a homicide? Since D2 clearly is not liable for a homicide (no one died), D1 isn't either. Both are liable solely for the peril they caused (or eventuated), and not for the fortuity of how events actually unfolded. Have I captured their position correctly?

Examine this simple case further. Had I fed the patron the bony chicken, would I be said to have created his peril when he proceeds to choke? Even here I am unsure. Do the chef and the waiter who prepared and served the chicken have a duty to assist the choking patron? Of course. But does the rationale of this duty depend on their causal role in creating his predicament? Their duty to assist is probably better grounded in their commercial relation with him than in their creation of his peril. If the victim had begun choking from some wholly unrelated malady—say, the symptoms of a coincidental heart attack-wouldn't the owners and operators of the restaurant still have a duty to assist him? The "creation of a peril" rationale seems inapt even here. To be sure, liability for omissions is a difficult topic, as is the analysis of causation. But I suspect that some of the situations in which Alexander and Ferzan 
would hold that an omission by a defendant creates a peril to be rectified are better analyzed as cases in which liability is not imposed for an omission at all, but rather for something else-for a complex act, or an ongoing course of conduct, for example.

I have described one of many such cases elsewhere. ${ }^{6}$ My example is designed to respond to Alexander and Ferzan's claim that "some cases of creation of the victim's peril are easy" (68). Indeed, some cases are easy, but (contra Ferzan and Alexander) the following is not among them. Suppose I am coasting along downhill in my car as it speeds along. Several moments after I remain motionless, my vehicle hits a pedestrian who I observe to be standing immobile in the middle of the highway, confident that any approaching car would stop before it strikes him. My car is damaged, and the pedestrian is injured. I have absolutely no doubt whatever that I am and ought to be liable for the injuries to the pedestrian: I could and should have applied my brakes. That much is easy. What I dispute is that the rationale for holding me liable is that I have created the pedestrian's peril. I see no more basis for saying that $I$ have created the pedestrian's peril, and thus am liable for the injury I inflicted via my omission, than for saying that he (that is, the pedestrian) has created my peril, and thus is liable for the damage to my car he inflicted via his omission. As far as the "creation of peril" rationale is concerned, the argument is a stalemate; we have created the peril of one another. His personal injury and my property damage both counterfactually depend on the faulty conduct of each other. Thus, I demur when Alexander and Ferzan write "[i]f, for example, one is driving, one is typically placing other drivers and pedestrians in peril unless one engages in various affirmative acts" (68). Why is this claim true of driving, but not of walking? One might as well say "if, for example, one stands in the middle of a highway, one is typically placing other drivers and vehicles in peril unless one engages in various affirmative acts." It is true that the extent of harms risked by drivers are generally asymmetrical to those risked by pedestrians, but why does this asymmetry show that the former create the peril of the latter? I believe that candor requires us to identify an altogether different rationale than that my conduct "creates the peril" to explain why I should be liable for the injuries to the pedestrian in my example. Although no solution is unproblematic, I suspect that the best analysis would not predicate my liability on an omission at all. In other words, this example is far from an "easy case" in which I create the pedestrian's peril that culminates in harm through my subsequent omission. Where Alexander and Ferzan insist that I have injured a pedestrian through an omission whose peril I have created, I tend to think I have injured a pedestrian through a complex act or a course of conduct. Omissions are included within this complex act or course of conduct, but they are not the basis for a finding of liability. ${ }^{7}$

I have tried to describe how the treatment of omissions by Alexander and Ferzan inherits but tries to gloss over many of the problems of their general approach. For starters, it invokes causation in disguise, involves real rather than subjective probabilities, and requires objective wrongdoing. To be consistent, what they should

\footnotetext{
6 See Douglas Husak: "Courses of Conduct," in Dana K. Nelkin and Samuel C. Rickless, eds.: The Ethics and Law of Omissions (New York: Oxford University Press, 2017), p. 165.

7 Id.
} 
have said is that liability for omissions depends on a determination of the risks of various harms to the morally protected interests of others the defendant believes his conduct endangers. There is no more need for diverse "triggers" of liability when conduct consists of an omission than when it consists of a positive act. Only one crime exists, and it can manifest itself in an act or an omission. But the application of this position is too radical for them to accept. If I believe I am violating a legally protected interest when I pass a panhandler or watch a patron choke in a restaurant, I am culpable for my behavior. The fact that they have the good sense not to run off this cliff in the context of omissions should have given them pause when they apply their theory elsewhere.

\section{Ignorance and Culpability}

Next, I want to briefly comment on Alexander and Ferzan's thoughtful treatment of moral ignorance, the topic they allege to present "the greatest challenge to our theory of criminal law" (107) the "significance" of which they "cannot overemphasize" (100). In my judgment, their more detailed examination of this issue improves greatly over their cursory account in Crime and Culpability. As with their treatment of omissions, however, I believe they again balk at accepting the implications of their own theory. Recall that Alexander and Ferzan hold that culpability consists in the risks of various harms to the morally protected interests of others the defendant believes his act endangers. Suppose in a given case the defendant believes his act endangers no morally protected interest. In my terminology, he believes his act is permissible, that is, not wrongful. On this stipulation, the determination of his culpability should be crystal clear: he has no culpability whatsoever. Thus, inasmuch as liability depends entirely on culpability, and culpability is wholly subjective, the defendant should not be liable. Alexander and Ferzan pay me a compliment by wrestling with my reasoning in support of the conclusion I believe they should have drawn. Still, they express reluctance to explicitly embrace my position. Although oftentimes their overall theory is breathtakingly radical, they mysteriously lose the courage of their convictions on the topic of moral ignorance.

Alexander and Ferzan follow me in distinguishing two broad traditions (or theories) of moral blameworthiness: "quality-of-will theories," and "reason-responsiveness theories" (95). Obviously, each of these general traditions admits of countless variants. But if some version of either of these familiar views is correct, culpability consists either in what a wrongdoer's act reveals about the nature of his will, or in whether a wrongdoer exhibits some defect in his responsiveness to reasons. I tend to favor the latter kind of theory, despite my inability to construct a decisive argument against the former. As Alexander and Ferzan express the matter, "if an individual does not see something as a moral reason, he cannot be responsive to it, and thus he is not blameworthy" for his failure to conform to it (95). I would formulate the claim slightly differently: No one should be expected to respond to a reason he does not believe he has. Thus we agree. At other times, however, I confess to being tempted by some versions of a quality-of-will theory. The whole field of moral responsibility is in a state of philosophical flux and intuitions in this domain are unlikely to 
be trustworthy. Even so, the two considerations Alexander and Ferzan cite do not incline me away from a reason-responsiveness theory and toward a quality of will theory. If a quality of will theory has appeal, which I do not deny (despite ultimately rejecting it), its attractions do not come from either of the grounds Alexander and Ferzan provide.

First, they cite Victor Tadros to express the worry that this reason-responsiveness view fails to make "intuitive sense of our judgments about the most egregious criminals" (96). "There is a serious problem to [a] view" if Hitler turns out not to be blameworthy for his atrocities (96), and any theory that would exculpate such a monster makes "our ordinary moral judgments seem highly questionable" (96). I find it odd that Alexander and Ferzan appeal to "our ordinary moral judgments" to question a commitment; their own theory is riddled with implications that offend common sense morality. In any event, as I have said, on the topic of moral responsibility for wrongdoing, almost any view-including the view that no one is ever morally responsible for anything-has been defended by respectable philosophers and should not be rejected out of hand. Intuitions about blameworthiness (apart from wrongdoing) are all over the place; one need only consider the split of opinion about the force of Frankfurt-style counterexamples to the principle of alternate possibilities. I suspect that Hitler looms as a plausible candidate for blameworthiness even on a reason-responsiveness view because it is so hard to imagine that he really was entirely ignorant of the immorality of his actions. Any number of Germans called his attention to the horror of what he was doing; indeed, he executed thousands of these dissenters. But I must leave historians to fathom the beliefs and motivations of the real Hitler. If we stipulate that Hitler was absolutely convinced he was making the world morally better by exterminating Jews, and recognized only moral reasons to proceed, I find his blameworthiness to become much more contentious.

Second, Alexander and Ferzan raise doubts about a reason-responsiveness theory of blameworthiness by favorably citing Michael Moore: "No choice theory of deontic blameworthiness can have choice go 'all the way down,' that is, require that before blame attaches, a choice must have been made about all the factors that cause choice and about all the aspects of the content of that choice" (96). I partly agree and partly disagree with this remark; its two clauses mix very different points. It is obviously true that no theory of blameworthiness can plausibly require persons to choose all of the factors that caused their choice. My birth is one of the causal factors of my choice, but no one chooses to be born. Causation, I submit, is not the relevant issue. But consider the second clause in this quotation. If I understand what it means to choose "all the aspects of the content of [my] choice," why is it similarly impossible for a theory of blameworthiness to require them to be chosen? Blameworthiness may attach only when I am aware of each of the features of my choice that make it wrong. As I construe this requirement of a reason-responsiveness theory, I must choose to engage in wrongdoing de dicto as well as de re in order to be blameworthy for it. This latter demand is hardly implausible; as so described, I am sure that many people actually make such choices in the real world.

Their foregoing two reservations notwithstanding, Alexander and Ferzan eventually join me in being partial to a reason-responsive theories of blameworthiness; they conclude that it "would appear to be the superior view" (97). Can it really be 
true, however, that no person is culpable and subject to liability unless he believes his conduct risks harm to a protected interest, that is, unless he believes his conduct is wrongful? Perhaps. But a more cautious view is that some morally ignorant defendants are somewhat culpable, although their degree of culpability is less than that of defendants who are fully aware they are acting wrongfully by endangering the morally protected interests of others. I have defended this position myself. ${ }^{8}$ I contend that in nearly any case in which two defendants commit the same wrongful act, and the first of whom believes it is wrong but the second does not, the first defendant is more culpable than the second, even if the second is somewhat blameworthy. Alexander and Ferzan, however, explicitly reject this more cautious view.

Consider the kind of case that I believe tests whether Alexander and Ferzan are correct to reject the more cautious view I mentioned above. In the sort of example I have in mind, morally ignorant defendants may be somewhat culpable, although their degree of culpability is less than that of those who are fully aware they are endangering others' morally protected interests. Suppose the defendant is unsure whether his act is permissible or wrongful. He is consciously aware that his conduct might violate a morally and legally protected interest - that is, he consciously disregards a substantial risk that his conduct is wrongful—but he goes ahead and acts anyway, despite the substantial risk he entertains. In such a scenario, if his act turns out to be wrongful, I think the defendant is culpable, although to a lesser extent than a defendant who knows his conduct violates a morally protected interest. This defendant is reckless with respect to whether his conduct is wrongful, and recklessness (ceteris paribus) is a lesser quantum of culpability than knowledge.

Curiously, however, Alexander and Ferzan deny the very possibility I have described. With respect to beliefs about moral propositions, at least, they insist "there is no middle ground" (101). For example, if "a father must decide whether an honor killing is morally required, all he can do is reach the conclusion that it is or is not. In deciding what morality requires, there is no room left for the belief that he might be unjustifiably (recklessly) wrong as opposed to wrong simpliciter" (101). I confess that I do not understand why they reach this all-or-nothing position. In my judgment, one can be uncertain of moral propositions as well as of empirical propositions. In fact, moral uncertainty is ubiquitous; philosophers write whole books as well as dissertations about the phenomenon. I am uncertain, for example, about the permissibility of given ways of treating non-human animals. On some occasions I go ahead despite this uncertainty; on other occasions I desist. Why, at the end of the day, am I committed to the conclusion that I must believe a given act is either right or wrong?

A particular view about the nature of belief probably underlies Alexander and Ferzan's claim that reckless beliefs about moral propositions is incoherent. Admittedly, beliefs are more curious than legal philosophers have tended to suppose. If it is true that I assign a credence to every given moral proposition, and I could be said to believe a proposition if and only if my credence exceeds a given threshold (say,

\footnotetext{
${ }^{8}$ But see Douglas Husak: Ignorance of Law: A Philosophical Inquiry (Oxford: Oxford University Press, 2016).
} 
$50 \%$ ), then either I believe or I do not believe every given moral proposition. No room is left for a middle ground to be occupied by recklessness. My main problem with this argument is that it proves too much. It cannot be confined to moral propositions; this argument similarly shows that I must believe or not believe every factual proposition. ${ }^{9}$ In my judgment, this conclusion oversimplifies the epistemic position of agents. With respect to a great many matters of fact and value, quite a few of us remain wholly clueless. That is, I could not begin to assign a credence to every given moral or factual position. I have no clear idea how I would estimate the probability, for example, that I am correct to allow my cat to roam outdoors. I am aware of a nontrivial risk that I might be wrong when I do so. A more specific level of credence, however, eludes me.

Whether or not the cautious position I described above is coherent, Alexander and Ferzan confess to being genuinely troubled by how moral ignorance bears on culpability. In the conclusion of their chapter, they admit the "potentially devastating challenge [posed by the issue of moral ignorance is] still standing. We urge all retributivists to come to our aid, as well as their own, and produce an adequate response to the challenge of moral ignorance" (107). I can hardly complain that they ask for assistance; we all need a little help from our friends. Among my reservations, however, is why they take the problem of moral ignorance to pose a special worry for retributivists. They fear that the thesis that morally ignorant persons are not culpable "is perhaps the greatest challenge to the retributivism that we endorse" (100). But why? If morally ignorant wrongdoers are not culpable, or (when reckless) are less culpable than those who act in full awareness their acts are wrongful, there still is plenty of room for retributive desert. It merely turns out that fewer persons are blameworthy and deserving of punishment than we may have thought initially. This conclusion, however, might well be welcomed by retributivists. We retributivists are often accused of contributing to overpunishment and overcriminalization. ${ }^{10}$ The conclusion I believe Alexander and Ferzan should have reached about the problem of moral ignorance provides an excellent opportunity for us to rebut this accusation without abandoning our retributivism.

On the topic of omissions as well as that of moral ignorance, I have accused Alexander and Ferzan of balking at what I regard as the relatively straightforward implications of their own theory. Oftentimes, and perhaps here, such unwillingness on the part of authors signals their deep ambivalence about whether they are correct. But enough criticism. Although I am aware of few if any legal philosophers who have signed on to Alexander and Ferzan's unusual theory of the criminal law, all theorists should relish the challenge of coming to terms with it and understanding at what point(s) and for what reason(s) they resist it. Their provocative treatment

\footnotetext{
${ }^{9}$ It is clear that skepticism about reckless beliefs about morality is extended to beliefs about all propositions. As they say (at p. 654), "there is no such thing as a reckless belief." See Larry Alexander and Kevin Cole: "Reckless Beliefs," in Larry Alexander and Kimberly Kessler Ferzan, eds.: The Palgrave Handbook of Applied Ethics and the Criminal Law (Cham: Palgrave-Macmillan, 2019), p. 651.

10 See Douglas Husak: Retributivism and (Over)Punishment," (forthcoming, Law and Philosophy).
} 
of omissions as well as that of moral ignorance provides excellent opportunities for philosophers of penal law to rethink what to accept and what to reject about their overarching view. I have often said both to their faces and behind their backs that there are no criminal theorists I like and respect more but agree with less. For the most part, my reading of Reflections on Crime and Culpability reinforces this judgment. I have barely scratched the surface in discussing the mountains of fascinating material this book contains. I strongly encourage all philosophers of criminal law to try to solve the many novel problems and puzzles Alexander and Ferzan deftly present.

Open Access This article is licensed under a Creative Commons Attribution 4.0 International License, which permits use, sharing, adaptation, distribution and reproduction in any medium or format, as long as you give appropriate credit to the original author(s) and the source, provide a link to the Creative Commons licence, and indicate if changes were made. The images or other third party material in this article are included in the article's Creative Commons licence, unless indicated otherwise in a credit line to the material. If material is not included in the article's Creative Commons licence and your intended use is not permitted by statutory regulation or exceeds the permitted use, you will need to obtain permission directly from the copyright holder. To view a copy of this licence, visit http://creativecommons.org/licen ses/by/4.0/.

Publisher's Note Springer Nature remains neutral with regard to jurisdictional claims in published maps and institutional affiliations. 